\author{
LIN SHEYU ${ }^{1}$, LI TONGCHUAN ${ }^{2}$, ZHU DENGNAN ${ }^{2}$, MA CAIYUN ${ }^{3}$, \\ WANG YINGHONG ${ }^{4}$, HE LIN ${ }^{1}$, ZHU CHANGLIAN ${ }^{2}$, XING QINGHE \\ ${ }^{1}$ Children's Hospital of Fudan University, Shanghai, China \\ E-mail: linsheyu@yeah.net \\ ${ }^{2}$ Department of Pediatrics, the Third Affiliated Hospital of Zhengzhou University, China \\ ${ }^{3}$ Department of Pediatrics, Zhengzhou Children's Hospital, Zhengzhou, China \\ ${ }^{4}$ Department of Pediatrics, the First Affiliated Hospital, Henan Traditional Chinese Medical College, Zhengzhou, China
}

\title{
THE ASSOCIATION BETWEEN GAD1 GENE POLYMORPHISMS AND CEREBRAL PALSY IN CHINESE INFANTS
}

\begin{abstract}
Studies suggest that GAD1 gene was a functional candidate susceptibility gene for cerebral palsy (CP). In order to investigate the contribution of GAD1 gene to the etiology of $C P$ in Chinese infants, we carried out a case-control association study between GAD1 gene and CP. In this study, 374 health controls and 392 infants with CP were recruited. Genomic DNA was extracted from venous blood and all three single nucleotide polymorphisms in GAD1 (rs3791874, rs3791862 and rs 16858977) were genotyped by Sequenom's MassARRAY system. There were no significant differences in allele or genotype frequencies between $C P$ or mixed CP patients and controls at any of the three genetic polymorphisms. Through haplotype analysis we found that haplotype $G G$ (rs3791862, rs 16858977) frequency demonstrated significantly statistical difference between mixed $C P$ patients and controls $(p=0.0371)$. Our positive findings of haplotype GG suggested that variation of GAD1 gene was an important risk factor for mixed $C P$.
\end{abstract}

Keywords: glutamate decarboxylase 1; single nucleotide polymorphism; haplotype; mixed $C P$.

Introduction. Cerebral palsy (CP), which usually occurs in the developing fetal and infant, is defined as a non-progressive but not unchanging disorder of posture or movement resulting from an abnormality of the brain [1, 2]. The major clinical manifestations include spastic diplegia, mental retardation, hyperreflexia, clumsiness, unstable gait and drooling. Different individuals have some phenotypic variability, but spastic diplegia, and mental retardation are three constant traits presented in all affected individuals [3]. According to the overall clinical picture, CP can be classified into such subgroups as dyskinetic, ataxic, spastic and mixed CP [4, 5]. Approximately 2-3/1000 live births present with $\mathrm{CP}$, which makes it one of the most common physical disability of childhood [6]. Although the aetiology of $\mathrm{CP}$ has been attributed to a variety

(C) LIN SHEYU, LI TONGCHUAN, ZHU DENGNAN, MA CAIYUN, WANG YINGHONG, HE LIN, ZHU CHANGLIAN, XING QINGHE, 2013 of factors, the detailed mechanisms underlying most cases remain elusive. Asphyxia, neuronal disorders, infections in utero, amnionitis, maternal autoimmune disease, metabolic disease, vascular lesions, as well as coagulation disorders all have been considered as risk factors for CP [7]. It is unknown that how the fetus responds in the presence of these risk factors and how the genetic makeup influence the fetus response on the condition that some genotypes create susceptibility to cerebral damage. To date, a lot of casecontrol studies have been carried out to investigate the association between genetic polymorphisms and $\mathrm{CP}$. These studies have explored many genes, such as interleukin-6 (IL-6), apolipoprotein E (APOE), and cytokine, but the association between $G A D 1$ and $\mathrm{CP}$ has not been investigated [8-10].

$G A D 1,46 \mathrm{~kb}$ in length, with 17 exons, located in $2 \mathrm{q} 31$, codes for the $67 \mathrm{kDa}$ isoform (GAD67) of L-glutamate decarboxylase. GAD67 is one of the two major isoforms of GAD, an enzyme that converts glutamate to GABA. The other isoform, GAD65, is encoded by the gene GAD2. GAD67 exists as both homo- and heterodimers in both soluble and membrane-bound forms, primarily within the cell soma but also to a limited degree in terminals [4, 11]. A great many of evidences indicated that $G A D 1$ played more and more important role in nerve system disease such as autism and schizophrenia. Many studies on the association between GAD1 and nerve system diseases have been conducted and their results proved that the abruption of $G A D 1$ gene was an important risk factor to the happening of schizophrenia, autism and child bipolar I disorder [11-14]. There was also a study which demonstrated that $G A D 1$ was associated with cortical gray matter volume loss in schizophrenia [15]. In addition, the linkage between GAD1 and cerebral palsy has been explored and the linkage region has been mapped to chromosome 2q24-25. A missense mutation in GAD67 was detected, which was segregated 
with $\mathrm{CP}$ in affected individuals $[4,16]$. However, whether the association between GAD1 and cerebral palsy in population exists has not been known yet. In order to investigate the association, we enrolled 374 health controls and 392 infants with CP. The association analysis showed that no significant differences existed in allele or genotype frequencies between $\mathrm{CP}$ and controls. However, gene GAD1 with GG haplotype would more possibly increase the incidence of mixed CP.

Materials and methods. Subjects. The study population was comprised of $392 \mathrm{CP}$ patients (118 girls $30.1 \%$, 274 boys $69.9 \%$, mean age \pm s.d.: $18.25 \pm$ \pm 14.64 months) chosen from center for CP rehabilitation in the Third Affiliated Hospital of Zhengzhou University, Zhengzhou Children's Hospital and the First Affiliated Hospital of the Henan Traditional Chinese Medical College from 1 May 2008 to 31 Oct 2009. Among the 392 cases, 159 cases suffered from spastic quadriplegia cerebral palsy and 93 cases suffered from mixed cerebral palsy. The 374 healthy controls included in the study were selected from the Child Healthcare Department at the same hospital during the same period and were matched for age, sex and ethnicity (154 girls $41.18 \%, 220$ boys $58.82 \%$, mean age \pm s.d.: $18.40 \pm 19.55$ months). All subjects including CP patients and healthy controls belonged to Chinese Han population and written informed consent was asked from each subject. Symptoms of CP patients were assessed by a child neurologist with clinical examination or with medical records. This study was approved by the ethics committee of Zhengzhou University in accordance with the Helsinki declaration.
SNP selection. In this study, the SNP was selected according to the criterion of heterozygosity more than $15 \%$ and minor allele frequencies (MAF) more than $5 \%$. A total of three SNPs were selected. Rs3791874 in intron 2 was selected because it was close to missense mutation (G36C) [4]. We consulted the HapMap database (release\#2, population: Han Chinese in Beijing) and selected tagging SNP rs3791862 in intron 3. In the middle part of gene GAD1 rs16858977 (intron 7) was selected since it could represent the largest block according to LD heat plot and CHB phased haplotypes in HapMap database.

Genotyping. Genomic DNA was extracted from venous blood using AxyPrep Blood Genomic DNA Miniprep Kit (Axygen Biosciences, Union city, CA, USA) and following the recommended procedure. SNP genotyping was performed using Sequenom's MassARRAY system (San Diego, California, USA) according to the manufacturers' specifications. Results were analyzed with Typer4.0 software (Sequenom). Those whose genotype results were analyzed were blind to the clinical data.

Statistical analysis. We conducted Hardy-Weinberg equilibrium tests with Hardy-Weinberg test 3.0.xls, allele and genotype frequency, linkage disequilibrium and haplotype analysis with the SHESIS software. The haplotype blocks were defined as $\mathrm{D}^{\prime}>0.8$. Linkage disequilibrium was measured using standardized $\mathrm{D}^{\prime}$ and $\mathrm{r}^{2}$, and the discrepancies in allele and genotype frequencies on single locus between patients and controls were compared using a Fisher's exact test strategy. The numbers of observations for each haplotype were compared using $\chi^{2}$ tests

Table 1. Allele and genotype frequencies of SNPs in GAD1

\begin{tabular}{|c|c|c|c|c|c|c|c|c|}
\hline Group & \multicolumn{2}{|c|}{ Allele frequency } & $\mathrm{P}$ & \multicolumn{3}{|c|}{ Genotype frequency } & $P$ & $\mathrm{H}-\mathrm{W}$ \\
\hline rs3791874 & $\mathrm{G}$ & $\mathrm{T}$ & & $\mathrm{G} / \mathrm{G}$ & $\mathrm{T} / \mathrm{T}$ & $\mathrm{G} / \mathrm{T}$ & & \\
\hline $\mathrm{CP}$ & $425(0.5491)$ & $349(0.4509)$ & 0.9591 & $112(0.2894)$ & $74(0.1912)$ & $201(0.5194)$ & 0.9922 & 0.3363 \\
\hline MCP & $28(0.5385)$ & $26(0.4615)$ & 0.6495 & 7 (0.2593) & $6(0.2222)$ & $14(0.5185)$ & 0.8903 & 0.8420 \\
\hline Control & $404(0.5504)$ & $330(0.4496)$ & & $106(0.2888)$ & $69(0.1880)$ & $192(0.5232)$ & & 0.2743 \\
\hline rs3791862 & $\mathrm{G}$ & $\mathrm{T}$ & & $\mathrm{G} / \mathrm{G}$ & $\mathrm{T} / \mathrm{T}$ & $\mathrm{G} / \mathrm{T}$ & & \\
\hline $\mathrm{CP}$ & $559(0.7222)$ & $215(0.2778)$ & 0.9216 & $196(0.5065)$ & $24(0.0620)$ & $167(0.4315)$ & 0.3319 & 0.1375 \\
\hline $\mathrm{MCP}$ & $39(0.7800)$ & $11(0.2200)$ & 0.3582 & $14(0.5600)$ & $0(0.0000)$ & $11(0.4400)$ & 0.3139 & 0.1580 \\
\hline Control & 527 (0.7199) & $205(0.2801)$ & & $192(0.5246)$ & $31(0.0847)$ & $143(0.3907)$ & & 0.5520 \\
\hline rs16858977 & $\mathrm{C}$ & $\mathrm{G}$ & & $\mathrm{C} / \mathrm{C}$ & $\mathrm{G} / \mathrm{G}$ & $\mathrm{C} / \mathrm{G}$ & & \\
\hline $\mathrm{CP}$ & $237(0.3329)$ & $475(0.6671)$ & 0.9385 & $37(0.1093)$ & $156(0.4382)$ & $163(0.4579)$ & 0.6301 & 0.5597 \\
\hline $\mathrm{MCP}$ & $13(0.2708)$ & $35(0.7292)$ & 0.3626 & $1(0.0417)$ & $12(0.5000)$ & $11(0.4583)$ & 0.6129 & 0.0030 \\
\hline Control & $225(0.3348)$ & $447(0.6652)$ & & $30(0.0893)$ & $141(0.4196)$ & $165(0.4911)$ & & 0.0604 \\
\hline
\end{tabular}


between cerebral group and control group or between mixed cerebral palsy (MCP) sub-group and control. Correction of permutation test was applied to haplotype analysis. All reported P-values were two-tailed and statistical significance was set at $\mathrm{P}<0.05$.

Results. In this association study using $392 \mathrm{CP}$ patients and 374 healthy controls, we tested three SNPs in GAD1 gene. The genotypic distribution of the three SNPs was in Hardy-Weinberg equilibrium in both the patient group (except rs16858977 in MCP group) and the control group. Allele frequencies and genotypic distribution analysis of individual SNPs are shown in Table 1. For the totality of the subjects, there were no significant differences of allele or genotype frequencies between CP patients and controls at any of the three genetic polymorphisms. The similar results were observed between MCP and controls.

We investigated LD for all possible two-way comparisons among the three selected SNPs in GAD1. Analysis of $\mathrm{D}^{\prime}$ revealed strong linkage disequilibrium $\left(\mathrm{D}^{\prime}>0.8\right)$ between rs3791874 and

Table 2. The linkage disequilibrium among the SNPs

\begin{tabular}{|c|c|c|c|c|c|c|}
\hline Index & & Case & & & $\mathrm{MCP}$ & \\
\hline $\mathrm{D}^{\prime} / \mathrm{r}^{2}$ & rs3791874 & rs3791862 & rs16858977 & rs3791874 & rs3791862 & rs16858977 \\
\hline rs3791874 & & 0.968 & 0.147 & & 0.979 & 0.140 \\
\hline rs3791862 & 0.443 & & 0.988 & 0.444 & & 0.976 \\
\hline rs16858977 & 0.000 & 0.207 & & 0.008 & 0.196 & \\
\hline
\end{tabular}

Table 3. Estimated GAD1 haplotype frequencies

\begin{tabular}{c|c|c|c|c}
\hline \multirow{2}{*}{ Haplotype } & \multicolumn{2}{|c|}{ Frequency } & \multirow{2}{*}{ P-value } & OR (95 \% CI) \\
\cline { 2 - 3 } & CP & Controls & \\
\hline rs3791874, rs3791862 & & & \\
G G & $415.99(0.5445)$ & $395.01(0.5471)$ & 0.9617 & $0.9950(0.8107,1.2212)$ \\
T G & $134.01(0.1754)$ & $125.99(0.1745)$ & 0.9470 & $1.0091(0.7720,1.3191)$ \\
T T & $210.02(0.2749)$ & $198.98(0.2756)$ & 0.9975 & $0.9996(0.7959,1.2555)$ \\
rs3791862, rs16858977 & & & \\
G C & $235.03(0.3329)$ & $219.98(0.3323)$ & 0.9990 & $1.0001(0.7985,1.2526)$ \\
G G & $262.00(0.3711)$ & $243.02(0.3671)$ & 0.8940 & $1.0151(0.8148,1.2646)$ \\
T G & $208.98(0.2960)$ & $198.00(0.2991)$ & 0.8872 & $0.9833(0.7798,1.2401)$ \\
\hline
\end{tabular}

Table 4. Estimated GAD1 haplotype frequencies

\begin{tabular}{c|c|c|c|c}
\hline \multirow{2}{*}{ Haplotype } & \multicolumn{2}{|c|}{ Frequency } & \multirow{2}{*}{ P-value } & OR (95\% CI) \\
\cline { 2 - 3 } & MCP & Controls & & \\
\hline rs3791874, rs3791862 & & & \\
G G & $28.00(0.5600)$ & $395.01(0.5471)$ & 0.8756 & $1.0472(0.5879,1.8654)$ \\
T G & $11.00(0.2200)$ & $125.99(0.1745)$ & 0.4211 & $1.3297(0.6628,2.6675)$ \\
T T & $11.00(0.2200)$ & $198.98(0.2756)$ & 0.3866 & $0.7384(0.3708,1.4704)$ \\
rs3791862, rs16858977 & & & & \\
G C & $12.00(0.2609)$ & $219.98(0.3323)$ & 0.3149 & $0.7075(0.3592,1.3933)$ \\
G G & $24.00(0.5217)$ & $243.02(0.3671)$ & $\mathbf{0 . 0 3 7 1}$ & $1.8765(1.0301,3.4184)$ \\
T G & $10.00(0.2174)$ & $198.00(0.2991)$ & 0.2371 & $0.6496(0.3161,1.3346)$ \\
\hline
\end{tabular}


rs3791862 or between rs3791862 and rs16858977. However, no linkage disequilibrium was observed between rs3791874 and rs16858977 (Table 2). Then we analyzed haplotype frequency in which rare haplotypes with a frequency less than 0.03 were dropped. In total, four individual haplotypes were observed and three showed a frequency greater than $3 \%$, among which no haplotype distribution produced positive results (Table 3 ) in CP group. In the exploratory analysis, where the sample was sub-grouped according to the clinical symptoms, significant evidence of preferential sharing of the haplotype GG in MCP subgroup $(\mathrm{p}=0.0371)$ was compared with control group (Table 4).

Discussion. Cerebral palsy comprises a group of permanent and non-progressive disorders of movement and posture caused by a central nervous lesion, damage or dysfunction originating early in life [17]. Although the aetiology of CP has been attributed to a variety of factors, the specific mechanism underlying most cases remains unknown. The efforts to reduce the incidence of perinatal brain injury in term infants have failed despite the improvement in obstetric and neonatal care [18, 19]. The genetic factors affecting CP have attracted more attention from researchers in recent years [20-22]. Many candidate genes have been found and identified as risk factors for CP. These candidate genes were categorized as cytokine, thrombophilic, apolipoprotein $\mathrm{E}$ and a group related to cardiovascular disease or functions of immune system. But the association study on candidate gene such as GAD1 related to nervous system development hasn't been reported yet.

In the present study of Chinese infants, there were no significant differences of allele or genotype frequencies between CP patients and controls at any of the three GAD1 gene polymorphisms. The results may be owing to these three SNPs are all located in intron and they are not functional variants of GADI. Then we performed the haplotype analysis. The haplotype (rs3791874 and rs3791862) did not show any significant difference between $\mathrm{CP}$ group and controls probably because the range from rs 3791874 to rs3791862 did not cover any natural variant or contain any functional region according to UniProt database. Thus we speculated that the haplotype (rs3791874 and rs3791862) probably did not alter the protein product of the gene and its catalytic activity. Similarly, the haplotype (rs3791862 and rs16858977) did not show any significant difference between $\mathrm{CP}$ group and controls probably due to the occurrence of cerebral palsy attributed to a variety of risk factors. However, further analysis showed that the haplotype GG (rs3791862, rs16858977) distribution revealed a significant difference between mixed CP patients and controls. Linkage disequilibrium tests demonstrated a strong linkage disequilibrium $\left(\mathrm{D}^{\prime}>0.8\right)$ between $\mathrm{rs} 3791874$ and rs3791862 or between rs3791862 and rs16858977. However, no marked linkage disequilibrium was found between rs3791874 and rs16858977. Given this, we supposed that rs3791862 was a newly formed SNP and might evolve because of gene-tic drift or positive Darwinian selection [23, 24]. According to this theory, the individuals with heterozygous status at rs 3791862 should present a prominent linkage disequilibrium between rs3791874 and rs16858977 and our results verified the hypothesis $\left(\mathrm{D}^{\prime}=0.95\right)$. Based on this, the haplotype (rs3791874, rs3791862 and rs16858977) were analyzed and results showed that the haplotype TGG distribution revealed a significant difference between $\mathrm{CP}$ group and controls $(\mathrm{p}=$ $=0.028)$ or between spastic quadriplegia $\mathrm{CP}$ group and controls $(\mathrm{p}=0.0358)$ or between mixed CP group and controls $(p=0.0052)$ (data not shown). These results provided a positive support for the haplotype GG as a risk factor for the occurrence of mixed CP. The significant difference of haplotype GG between mixed CP patients and controls was further supported by the genotype distribution in mixed CP group which displayed a prominent Hardy-Weinberg disequilibrium. In addition, the coverage area of selected SNPs added up to $64.23 \%$ in the whole GAD1 gene according to LD plot of CHB population in HapMap database. Based on these data, we speculated that gene GAD1 with haplotype GG should more possibly contribute to the occurrence of mixed CP.

There was a study documenting that $24 \%$ of term infants with CP had evidence of encephalopathy in the newborn period. Neonates with encephalopathy had significant deficits, memory impairment, visual dysfunction and increased hyperactivity. MCP is usually the spastic $\mathrm{CP}$ and the athetoid $\mathrm{CP}$ which combine to cause many disabilities in a child. Generally mixed CP was more severely affected and more often had dysgnosia, cerebral visual impairment and dyskinesia $[17,25,26]$. In our study, the majority of patient samples, especially MCP, have one or more of 
the following features: dysnoesia, dysarthria, visual perceptive dysfunction and hearing impairment. Spastic quadriplegia was often associated with cortical and subcortical white matter damage or extensive necrosis in the brain [27]. Based on these facts, we could see that $\mathrm{CP}$, especially mixed $\mathrm{CP}$, was more often caused by the cerebral injury. The $\gamma$-aminobutyric acid (GABA) was synthesized by GAD67 in neurons and served as neurotransmitters/neuromodulators in the regulation of the circulation and permeability of the intrinsic microvessels within the central nervous system (CNS) $[28,29]$. Baclofen, as a GABA agonist, was used to reduce muscle tone in $\mathrm{CP}$ children and to decrease spasticity and furthermore, improvement in comfort and function were both observed. All these studies implied that GAD1 was involved in occurrence of CP. These facts were consistent with our findings that gene GAD1 was associated with the occurrence of $\mathrm{CP}$, especially mixed CP.

Gender related pathophysiological features are thought to be related to CP [30]. Therefore, we checked the gender differences in genetic susceptibility to $\mathrm{CP}$, but found no association between the three GAD1 gene polymorphisms and CP. Prematurity is another important contributor to CP [31]. Gestation age differences with genetic susceptibility to $\mathrm{CP}$ were also compared in our study, but no difference was observed with respect to the GAD1 gene polymorphisms.

In conclusion, our results showed that none of the three SNPs in GAD1 contribute to the occurrence of $\mathrm{CP}$ in Chinese infants. However, gene GAD1 with GG haplotype is preferentially a risk factor for the occurrence of mixed CP. To our knowledge, this is the first report to demonstrate that $G A D 1$ is associated with occurrence of mixed CP. Nonetheless, it should be stated that our findings are still preliminary and have many limitations such as fewer SNPs, small sample size of mixed CP and limited coverage field in the gene. Therefore, the further study is warranted.

We are grateful to all the participants in this study. This work was supported by a grant from national natural science foundation of China (No: 90919049), the 973 Program (2010CB529600, 2007CB947300), the Shanghai Municipal Commission of Science and Technology Program (09DJ1400601) and the third phase of 211 project from Ministry of Education of China.
Lin Sheyu, Li Tongchuan, Zhu Dengnan, Ma Caiyun, Wang Yinghong, He Lin, Zhu Changlian, Xing Qinghe

СВЯЗЬ МЕЖДУ ПОЛИМОРФИЗМАМИ ГЕНА GAD1 И ЦЕРЕБРАЛЬНЫМ ПАРАЛИЧОМ У КИТАЙСКИХ ДЕТЕЙ

Предполагается, что ген GAD1 является функциональным кандидатом на роль гена подверженности церебральному параличу (ЦП). Для исследования вклада гена $G A D 1$ в этиологию ЦП у китайских детей методом случай - контроль проведено исследование ассоциации между наличием гена GAD1 и ЦП. В исследовании были задействованы 374 здоровых ребенка (контроль) и 392 ребенка с ЦП. Геномную ДНК выделяли из венозной крови, и все три единичных нуклеотидных полиморфизма гена GAD1 (rs3791874, rs3791862 и rs16858977) были генотипированы в системе Sequenom MassARRAY. Ни для одного из трех генетических полиморфизмов не обнаружено существенных различий в частотах аллелей или генотипов между больными ЦП или смешанными больными ЦП и контролем. Анализ гаплотипов показал существенные статистические различия в частоте гаплотипа GG (rs3791862, rs16858977) у смешанных больных ЦП и контрольной группы $(\mathrm{p}=0.0371)$. Позитивный результат по гаплотипу GG свидетельствует о том, что вариация гена GAD1 является важным фактором риска для смешанного ЦП.

\section{REFERENCE}

1. McHale D.P., Jackson A.P., Campbell et al. A gene for ataxic cerebral palsy maps to chromosome 9p12-q12 // Eur. J. Hum. Genet. - 2000. - 8, № 4. - P. 267-272.

2. Menkes J.H., Flores-Sarnat L. Cerebral palsy due to chromosomal anomalies and continuous gene syndromes // Clin Perinatol. - 2006. - 33, № 2. P. 481-501.

3. Rajab A.,Yoo S.Y., Abdulgalil A. et al. An autosomal recessive form of spastic cerebral palsy $(\mathrm{CP})$ with microcephaly and mental retardation // Amer. J. Med. Genet. - 2006. - 140, № 14. - P. 1504-1510.

4. Lynex C.N., Carr I.M., Leek J.P. et al. Homozygosity for a missense mutation in the $67 \mathrm{kDa}$ isoform of glutamate decarboxylase in a family with autosomal recessive spastic cerebral palsy: parallels with Stiff-Person Syndrome and other movement disorders // BMC Neurol. - 2004. - 4, № 1. - P. 20.

5. Reid S.M., Carlin J.B., Reddihough D.S. Distribution of motor types in cerebral palsy: how do registry data compare // Dev. Med. Child. Neurol. - 2011. - 53, № 3. - P. 233-238.

6. Moreno-De-Luca A., Helmers S.L., Mao H. et al. Adaptor protein complex-4 (AP-4) deficiency causes a novel autosomal recessive cerebral palsy syndrome

ISSN 0564-3783. Цитология и генетика. 2013. T. 47. № 5 


\section{The association between GAD1 gene polymorphisms and cerebral palsy in Chinese infants}

with microcephaly and intellectual disability // J. Med. Genet. - 2011. - 48, № 2. - P. 141-144.

7. $W u$ D., Zou Y.F., Xu X.Y. et al. The association of genetic polymorphisms with cerebral palsy: a metaanalysis // Dev. Med. Child. Neurol. - 2011. - 53, № 3. - P. 217-225.

8. Resch B., Muller W.D. Interleukin-6-174 CC polymorphism is associated with clinical chorioamnionitis and cerebral palsy // Ann. Neurol. - 2010. 68, № 5. - P. 768-769.

9. McMichael G.L., Gibson C.S., Goldwater P.N. et al. Association between Apolipoprotein E genotype and cerebral palsy is not confirmed in a Caucasian population // Hum. Genet. - 2008. - 124, № 4. - P. 411-416.

10. Gibson C.S., MacLennan A.H., Goldwater P.N. et al. The association between inherited cytokine polymorphisms and cerebral palsy // Amer. J. Obstet. Gynecol. - 2006. - 194, № 3. - P. 674 e1-11.

11. Straub R.E., Lipska B.K., Egan M.F. et al. Allelic variation in GAD1 (GAD67) is associated with schizophrenia and influences cortical function and gene expression // Mol. Psych. - 2007. - 12, № 9. - P. 854-869.

12. Chang S.C., Pauls D.L., Lange C. et al. Common genetic variation in the GAD1 gene and the entire family of DLX homeobox genes and autism spectrum disorders // Amer. J. Med. Genet. B. Neuropsych. Genet. - 2011. - 156, № 2. - P. 233-239.

13. Geller B., Tillman R., Bolhofner K. et al. GAD1 single nucleotide polymorphism is in linkage disequilibrium with a child bipolar I disorder phenotype // J. Child. Adol. Psychopharm. - 2008. - 18, № 1. - P. 25-29.

14. Du J., Duan S., Wang H. et al. Comprehensive analysis of polymorphisms throughout $G A D 1$ gene: a family-based association study in schizophrenia // J. Neural. Trans. - 2008. - 115, № 3. - P. 513-519.

15. Addington A., Gornick M., Duckworth J. et al. GAD1 (2q31.1), which encodes glutamic acid decarboxylase (GAD67), is associated with childhood-onset schizophrenia and cortical gray matter volume loss // Mol. Psych. - 2005. - 10, № 6. - P. 581-588.

16. McHale D.P., Mitchell S., Bundey S. et al. A gene for autosomal recessive symmetrical spastic cerebral palsy maps to chromosome 2q24-25 // Amer. J. Hum. Genet. - 1999. - 64, № 2. - P. 526-532.

17. Andersen G.L., Irgens L.M., Haagaas I. et al. Cerebral palsy in Norway: prevalence, subtypes and severity // Eur. J. Paediatr. Neurol. - 2008. - 12, № 1. - P. 4-13.

18. Shevell M.I., Majnemer A., Morin I. Etiologic yield of cerebral palsy: a contemporary case series // Pediatr. Neurol. - 2003. - 28, № 5. - P. 352-359.

19. Cheng X., Li T., Wang H. et al. Methylenetetra-hy- drofolate reductase gene polymorphisms and cerebral palsy in Chinese infants // J. Hum. Genet. - 2011. 56, № 1. - P. 17-21.

20. Thorarensen O., Ryan S., Hunter J., Younkin D.P. Factor $\mathrm{V}$ Leiden mutation: an unrecognized cause of hemiplegic cerebral palsy, neonatal stroke, and placental thrombosis // Ann. Neurol. - 1997. - 42, № 3. - P. 372-375.

21. Harum K.H., Hoon A.H.Jr., Casella J.F. Factor-V Leiden: a risk factor for cerebral palsy // Dev. Med. Child. Neurol. - 1999. - 41, № 11. - P. 781-785.

22. Costeff $H$. Estimated frequency of genetic and nongenetic causes of congenital idiopathic cerebral palsy in west Sweden // Ann. Hum. Genet. - 2004. - 68, № 5. - P. 515-520.

23. Masui S., Nakatome M., Matoba R. Variants of the melanocortin 1 receptor gene (MC1R) and $\mathrm{P}$ gene as indicators of the population origin of an indivi-dual // Int. J. Legal. Med. - 2009. - 123, № 3. - P. 205-211.

24. Mu J., Duan J., Makova K. D. et al. Chromosome-wide SNPs reveal an ancient origin for Plasmodium falciparum // Nature. - 2002. - 418, № 6895. - P. 323-326.

25. Morota N., Kameyama S., Masuda M. et al. Functional posterior rhizotomy for severely disabled children with mixed type cerebral palsy // Acta Neurochir. - 2003. - 87. - P. 99-102.

26. Ghasia F., Brunstrom J., Gordon M., Tychsen L. Frequency and severity of visual sensory and motor deficits in children with cerebral palsy: gross motor function classification scale // Invest. Ophthalmol. Vis. Sci. - 2008. - 49, № 2. - P. 572-580.

27. Shankaran $S$. Prevention, diagnosis, and treatment of cerebral palsy in near-term and term infants // Clin. Obstet. Gynecol. - 2008. - 51, № 4. - P. 829-839.

28. Cram D.S., Barnett L.D., Joseph J.L., Harrison L.C. Cloning and partial nucleotide sequence of human glutamic acid decarboxylase cDNA from brain and pancreatic islets // Biochem. Biophys. Res. Communs. - 1991. - 176, № 3. - P. 1239-1244.

29. Flace P., Benagiano V., Lorusso L. et al. Glutamic acid decarboxylase immunoreactive large neuron types in the granular layer of the human cerebellar cortex // Anat. Embryol. (Berl). - 2004. - 208, № 1. - P. 55-64.

30. Johnston M.V., Hagberg H. Sex and the pathogenesis of cerebral palsy // Dev. Med. Child. Neurol. 2007. - 49, № 1. - P. 74-78.

31. Nelson K.B., Dambrosia J.M., Iovannisci D.M. et al. Genetic polymorphisms and cerebral palsy in very preterm infants // Pediatr. Res. - 2005. - 57, № 4. P. 494-499.

Received 07.04.12 